\title{
En kvinne med muskelsvakhet og utslett
}

En kvinne utviklet proksimal muskelsvakhet, moderat funksjonsdyspné, og senere utslett og svelgevansker. Hun hadde normale verdier for kreatinkinase, og muskelbiopsi viste normale forhold. Etter en lang og grundig utredning kom man frem til en sjelden diagnose.

Se kommentar side 1650 og kunnskapsprøve på www.tidsskriftet.no/quiz

En 44 år gammel kvinne ble undersøkt ved revmatologisk poliklinikk pga. muskelsvakhet $i$ halvannet år. Hun fortalte at kraften hadde avtatt $i$ både armer og bein, og at hun spesielt merket dette når hun skulle sykle, eller gå opp trapper. I tillegg hadde hun følt seg sliten. Hun hadde også utviklet noe rødhet i begge kinn, som var mest uttalt når hun solte seg.

En måned etter starten på muskelplagene ble hun behandlet $i$ sykehus for pneumoni. Fastlegen påviste en positiv test for antinukleære antistoffer (ANA)(titer ukjent). Ved undersøkelse hos nevrolog ble det ved elektromyografi funnet mulige myopatiske forandringer.

Den kliniske undersøkelsen på revmatologisk poliklinikk avdekket normal muskelstyrke $i$ både armer og bein. Ved orienterende nevrologisk undersøkelse fant man ingen forstyrrelser $i$ sensibilitet, og perifere reflekser i bein og armer var normale. Lasègues test var negativ. MR av lårmuskulatur viste ingen tegn til aktiv muskelsykdom. Konsentrasjonen av kreatinkinase (CK), SR og CRP i serum var normale. ANA-testen var positiv (titer 160), men det ble ikke påvist noen subspesifisiteter. Anti-Jo-1-antistoff ble ikke påvist.

Pasientens muskelsvakhet var lokalisert proksimalt, og man mistenkte i første omgang primær muskelsykdom. MR av lårmuskulatur viste imidlertid ingen tegn til inflammasjon eller atrofi. Dette funnet samt fraværet av forhøyede verdier for muskelenzymer i serum talte sterkt imot polymyositt. Hun hadde heller ingen helt typiske hudforandringer som ved dermatomyositt (V-tegn, Sjal-tegn, Gottrons papler, periorbitalt heliotropt utslett). Anti-Jo-1-antistoff ble ikke påvist, og pasienten hadde ingen hoste og var ikke tungpustet. Det forelå derfor ingen mistanke om antisyntetasesyndrom.

Man overveide så muligheten av metabolsk myopati selv om pasienten ikke klart kunne relatere muskelsvakheten til fysiske anstrengelser. Det ble utført en iskemisk underarmstest, men denne ga ingen holdepunkter for metabolsk myopati. Subaerob arbeidstest var normal og ga ingen umiddelbar mistanke om mitokondriemyopati. Pasientens alder tilsa at det var mindre sannsynlig at det forelå en sporadisk inklusjonslegememyositt, og hos pasienter tidlig i 40-årene ses ikke polymyalgia rheumatica. Endokrinologisk var det ingen holdepunkter for sykdom i skjoldkjertel eller binyrer. Hun brukte ingen medisiner som kunne ha forklart en medikamentindusert myopati. Pasienten anga ingen generaliserte smerter, og man fant ingen ømme punkter (tender points). Fibromyalgi forelå derfor ikke. Pasienten ble observert uten sikker diagnose, og det ble ikke igangsatt behandling.

Pasientens muskelplager persisterte, og etter noen måneder utviklet hun et erytem baktil mellom skulderbladene og liknende forandringer fortil på brystet. Hun merket også noe tungpustethet ved fysiske anstrengelser, og problemer med å svelge fast føde.
Hun kom til kontroll ved revmatologisk poliklinikk. Verdiene for SR, CRP og CK var fremdeles normale. Som ledd i videre utredning av primær muskelsykdom ble det tatt biopsi fra $m$. vastus lateralis. Denne viste ingen tegn på muskelsykdom. Høyoppløsnings-CT (HRCT) av lunger viste imidlertid mattglassforandringer i høyre underlapp, og lungemedisinsk undersøkelse viste litt dårligere resultat ved gassdiffusjonstest (DICo var $80 \%$ av forventet). Funnene ga mistanke om restriktiv lungelidelse. Røntgenkontrastundersøkelse av spiserør viste uttalt distal dysmotilitet. På direkte spørsmål medga hun utvikling av lette, tofasiske Raynaud-fenomener lokalisert til føtter de siste måneder. Utslettet på brystet var typisk for såkalt V-tegn, og forandringen baktil ble oppfattet som Sjal-tegn. Høyoppløsnings-CT viste senere progrediering med lette mattglassforandringer nå i begge lunger.

Pasientens kliniske symptomer og funn omfattet moderat proksimal muskelsvakhet, beskjeden funksjonsdyspné og mattglassforandringer på høyoppløsnings-CT av lunger, noe atypiske Raynaud-fenomener, dysmotilitet av distale spiserør, samt hudforandringer i form av V-tegn og Sjal-tegn. Den mest sannsynlige diagnose var derfor amyopatisk, eller hypomyopatisk dermatomyositt. Det ble startet behandling med kortikosteroider i form av prednisolon per os $10 \mathrm{mg} \times 1$

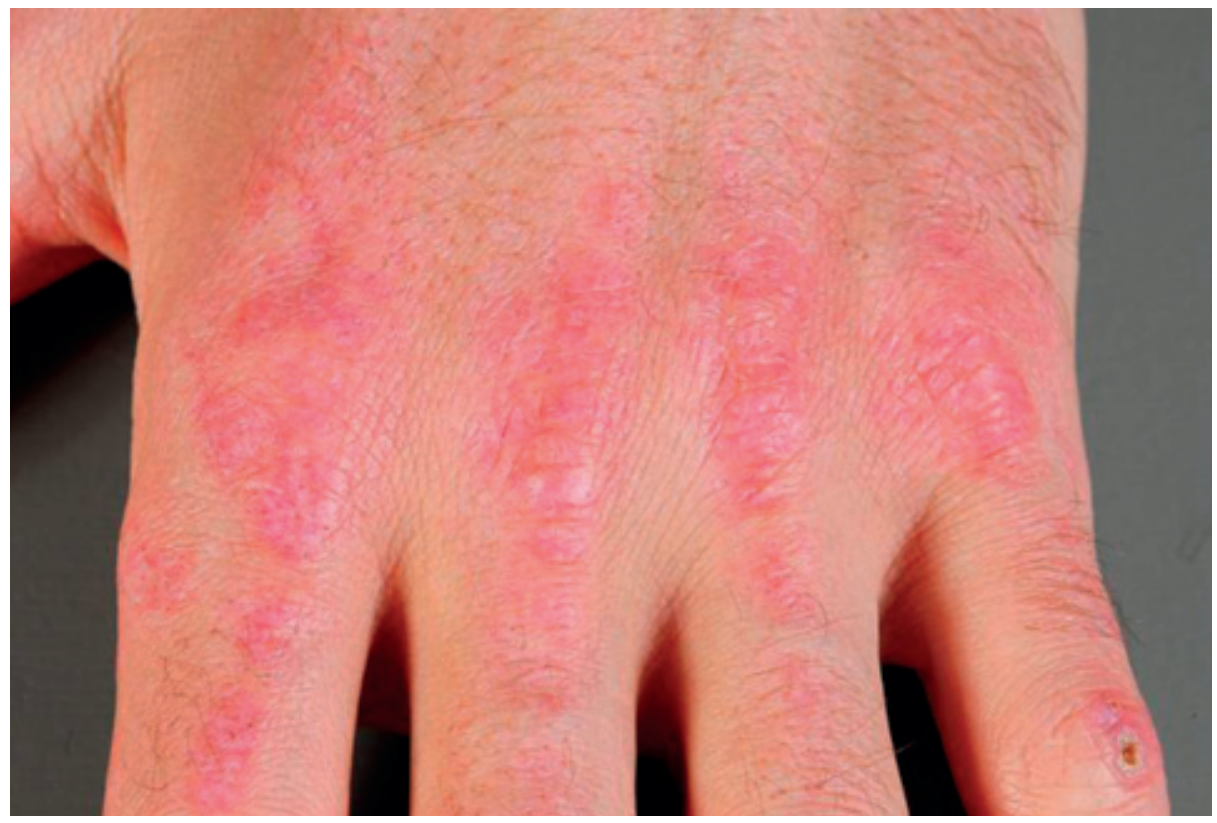

Figur 1 Gottrons papler. Erytematøse forandringer over fingerknoker 


\section{Ramme 1}

\author{
Diagnostiske overveielser \\ ved proksimal muskelsvakhet \\ Inflammatorisk myopati (polymyositt \\ og dermatomyositt) \\ Myopati som del av annen inflamma- \\ torisk/autoimmun sykdom \\ Metabolsk myopati \\ Inklusjonslegememyositt \\ Nerverotsaffeksjon \\ Tyreoidittassosiert myopat \\ Cancerassosiert myopati \\ Mitokondriemyopati \\ Medikamentindusert myopati \\ Sarkoidose (sjelden) \\ Muskeldystrofier
}

samt azatioprin $50 \mathrm{mg}$ to ganger daglig. Hun ble samtidig utredet for mulig ledsagende malign lidelse.

Ved kontroll tre måneder senere var utslettet i tilbakegang, og muskelsvakheten var noe mindre uttalt.

\section{Diskusjon}

Utredning av muskelsymptomer er en klinisk utfordring. Noen av de sykdommer man bør overveie ved symptomer lokalisert til ekstremitetsmuskulatur er vist i tabell 1 . Tabell 2 viser noen av de forhold som bør kartlegges ved utredning av slike pasienter.

Initialt hadde pasienten symptomer som tydet på primær muskelsykdom. Plagenes lokalisasjon proksimalt og med svakhet fremfor smerter, eller stivhet som dominerende symptom ga grunn for en slik mistanke. Mistanken ble styrket av funnene ved elektromyografi som viste myopatiske trekk. Normale verdier for kreatinkinase i serum og normale kraftprestasjoner ved testing av muskelstyrke svekket imidlertid sannsynligheten for at det forelå en inflammatorisk myopati av typen polymyositt. Pasienten hadde ved sykdomsstart heller ingen hudforandringer som kunne gi mistanke om dermatomyositt. Man hadde derfor tidlig i sykdomsforløpet ingen sikre holdepunkter for inflammatorisk myopati.

Man overveide så muligheten av en metabolsk myopati. Her vil man hos de fleste pasienter finne at muskelsymptomene $\mathrm{i}$ form av svakhet og smerter har sammenheng med fysiske anstrengelser. Ved forstyrrelser i glukolysen vil ofte symptomene forsterkes, eller utvikles like etter fysisk anstrengelse, mens ved forstyrrelser i lipidstoffskiftet kan symptomforsterking komme lenge etter fysisk anstrengelse. Pasienten anga ingen muskelsmerter, og muskelsvakheten var til stede under og ikke etter fysiske anstrengelser. Har man mistanke om metabolsk myopati, kan det være aktuelt å måle verdiene av kreatinkinase etter at pasienten har gjennomgått en fysisk anstrengelse. Dette ble ikke utført. Iskemisk underarmstest og senere histologisk undersøkelse av lårmuskel med spesialfarging ga imidlertid ingen holdepunkter for metabolsk myopati.

Pasienten ble også utredet for mitokondriemyopati, myopati i forbindelse med systemisk bindevevssykdom, endokrin myopati og inklusjonslegememyositt. Det var ingen holdepunkter for noen av disse tilstandene.

Pasientens endelige diagnose ble amyopatisk, eller mer korrekt hypomyopatisk dermatomyositt (1). Pasienter med amyopatisk dermatomyositt har hudmanifestasjoner som ved dermatomyositt (heliotropt utslett, Gottrons tegn og papler, V-tegn og Sjal-tegn) (fig 1), men ingen muskelsymptomer eller laboratoriefunn (elektromyografi eller muskelbiopsi) tydende på muskelsykdom. Ved hypomyopatisk dermatomyositt har pasienten moderate muskelsymptomer, men ingen laboratoriemessige holdepunkter for muskelinflammasjon. Ved begge sykdomsvarianter opptrer ofte fotosensitivitet og hudkløe (1). Prevalens og insidens av disse variantene av dermatomyositt er ukjent, men begge er svært sjeldne.

Hos pasienter med hudmanifestasjoner forenlig med dermatomyositt, men uten muskelsymptomer, kan man ved kapillaroskopi påvise forandringer som kan understøtte diagnosen. Denne undersøkelsen fremstiller kapillarene i neglesengen. Forandringer som blødninger, nedsatt kapillartetthet, og funn av megakapillarer og endret kapillararkitektur tyder på vaskulopati og er forenlig med diagnosen dermatomyositt. Dessverre ble ikke denne undersøkelsen utført hos vår pasient før sent i sykdomsforløpet. Undersøkelsen viste da noe endret arkitektur og redusert kapillartetthet, men ingen blødninger.

Ved amyopatisk og hypomyopatisk dermatomyositt foreligger det en betydelig risiko for utvikling av interstitiell lungesykdom $(2,3)$ hvilket ble påvist hos vår pasient tidlig i sykdomsforløpet. Hos noen pasienter kan man påvise forandringer ved høyoppløsnings-CT av lunger før symptomer på lungesykdom utvikles (4). Videre har slike pasienter samme risiko for koeksisterende malignitet som pasienter med klassisk dermatomyositt $(5,6)$. Slike pasienter skal derfor undersøkes nøye for kreftsykdom og følges regelmessig de tre første sykdomsårene.

Ved amyopatisk og hypomyopatisk dermatomyositt rettes behandlingen mot de kliniske manifestasjoner som dominerer sykdomsbildet. Hudlesjonene behandles oftest med hydroksyklorokin og lokale kortikosteroider. Behandlingen av interstitiell lungesykdom varierer med hvor alvorlig den er. Hos den aktuelle pasient fant man at lungeaffeksjonen var relativt moderat, og man

\section{Ramme 2}

\author{
Noen kliniske og laboratoriemessige \\ forhold som bør belyses i utredning \\ av pasient med muskelsymptomer \\ Sykehistorie \\ Alder \\ Familiær forekomst lsykdom i musk- \\ ler, sentralnervesystem, lever) \\ Skill mellom muskelsmerter, muskel- \\ stivhet og muskelsvakhet \\ Proksimal eller distal affeksjon \\ Muskelsymptomenes relasjon til \\ fysiske anstrengelser \\ Andre organmanifestasjoner (spesielt \\ lunge, hud og spiserør) \\ Medikamentforbruk (spesielt statiner) \\ Klinisk undersøkelse \\ Pareser \\ Atrofi \\ Orienterende nevrologisk unders $\varnothing$ - \\ kelse (sensibilitet, reflekser) \\ Hudmanifestasjoner \\ Generell undersøkelse llunger, mage, \\ bryster, gynekologisk, rektaleksplora- \\ sjon)
}

\section{Laboratorieutredning ved mistanke}

om primær muskelsykdom

- SR, CRP, leukocytter, trombocytter, leverenzymer

Kreatinkinase (CK)

MR av lårmuskulatur

Elektromyografi

Ved mistanke om metabolsk myopati

- S-laktat, frie fettsyrer, 3-hydroksybutyrat, karnitin og myoglobin

- Måling av CK etter fysisk anstrengelse

Utelukk tyreoiditt lautoantistoffer og TSH)

Ved mistanke om dermatomyositt

- Kapillaroskopi

- Anti-Mi-2-antistoff lantistoff med relativt god spesifisitet)

Laboratorieutredning dersom kreatinkinasenivåt er forhøyet, MR viser atrofi eller ødem, eller hvis elektromyografi viser myopatiske forandringer

Muskelbiopsi

- Ved utredning av metabolsk myopati: iskemisk underarmstest

Ved utredning av mitokondriemyopati: Subaerob arbeidstest

valgte behandling med perorale kortikosteroider og azatioprin. Hos andre noe mer affiserte pasienter ville man foretrukket en kombinasjon av perorale kortikosteroider og cyklofosfamid. En grunn til at man valgte azatioprin fremfor cyklofosfamid hos vår pasient, er den gunstigere bivirkningsprofilen hos førstnevnte. Ved alvorlig og progredierende lungesykdom vil man vurdere andre immunsuppressiver. 
Prognosen ved amyopatisk og hypomyopatisk dermatomyositt avhenger av graden av interstitiell lungesykdom og eventuell forekomst av ledsagende kreftsykdom. Hudlesjonene vil hos de fleste bedres eller tilheles nærmest fullstendig (7).

\section{Konklusjon}

Ved amyopatisk og hypomyopatisk dermatomyositt utvikles typiske hudmanifestasjoner, mens symptomer og funn av muskelsykdom kan være svært beskjedne, eller mangle helt. Tilstanden bør diagnostiseres tidlig da mange pasienter utvikler behandlingstrengende interstitiell lungesykdom, og risikoen for ledsagende kreftsykdom er den samme som for klassisk dermatomyositt.

\section{Jan Tore Gran}

jan.tore.gran@rikshospitalet.no

Revmatologisk avdeling

Oslo universitetssykehus, Rikshospitalet 0027 Oslo

Pasienten har gitt samtykke til at artikkelen blir publisert.

Oppgitte interessekonflikter: Ingen

\section{Litteratur}

1. Euwer RL, Sontheimer RD. Amyopathic dermatomyositis: a review. J Invest Dermatol 1993; 100 (suppl): $124-7$.

2. Gerami P, Schope JM, McDonald L et al. A systematic review of adult-onset clinically amyopathic dermatomyositis (dermatomyositis sine myositis) a missing link within the spectrum of idiopathic inflammatory myopathies. J Am Acad Dermatol 2006; 54: 597-613.
3. Ye S, Chen XX, Lu XY et al. Adult clinically amyopathic dermatomyositis with rapid progressive interstitial lung disease: a retrospective cohort study. Clin Rheumatol 2007: 26: 1647-54.

4. Miyazaki E, Ando M. Muramatsu T et al. Early assessment of rapidly progressive interstitial pneumonia associated with amyopathic dermato myositis. Clin Rheum 2007; 26: 436-9.

5. Osman Y, Narita M, Kishi K. Case report: amyopathic dermatomyositis associated with transformed malignant lymphoma. Am J Med Sci 1996: 311: $240-2$

6. Whitmore SE, Watson R, Rosenshein NB et al. Dermatomyositis sine myositis: association with malignancy. J Rheumatol 1996; 23: 1010-5.

7. Cosnes A, Amaudric F, Gheradi R. Dermatomyositis without muscle weakness: long term follow up of 12 patients without systemic corticosteroids. Arch Dermatol 1995; 131: 1381-5.

Manuskriptet ble mottatt 27.10. 2008 og godkjent 7.5. 2009. Medisinsk redaktør Odd Terje Brustugun

\section{Revmatologiske symptomer som varselsignal}

Pasienten i kasuistikken ovenfor ble omfattende utredet for muskelsymptomer og hudsymptomer. Etter hvert ble det satt i gang behandling med glukokortikosteroider og til slutt stilte man den sjeldne diagnosen hypomyopatisk dermatomyositt. Selv om denne spesifikke diagnosen er svært sjelden, vil en assosiasjon av muskelog hudsymptomer føre til at differensialdiagnosen dermatomyositt vurderes.

Ved polymyositt og dermatomyositt er det observert økt forekomst av malignitet. Malignitet må også has i mente ved andre revmatologiske symptomer. Ved denne kasuistikken med omfattende differensialdiagnostiske vurderinger er det praktisk viktig å huske at kreftsykdom også kan gi symptomer som kan oppfattes som revmatologiske.

En pasient med malign sykdom kan utvikle autoimmune fenomener eller revmatisk sykdom som følge av autoantistoffdanning mot autoantigener (for eksempel onkoproteiner) eller som paraneoplastisk syndrom med et vidt spekter av kliniske syndromer (1).

Det anslås at $7-10 \%$ av kreftpasienter utvikler paraneoplastisk syndrom (1). Hos pasienter med dermatomyositt, polymyositt, vaskulitt og systemisk sklerose er det påvist økning i risiko for utvikling av malignitet. Høy alder, rask debut av hud- eller muskelsymptomer, og periungvalt erytem er assosiert med malignitet ved dermatomyositt (2). Hematologisk malignitet kan manifestere seg som kutan vaskulittsyndrom. Imidlertid kan også artritt være utløst av malignitet og kan manifestere seg som en symmetrisk polyartritt, slik som ved revmatoid artritt (3).

En litteraturgjennomgang viser at cancerartritt er sjeldent, men må påregnes som differensialdiagnose ved sen debut av terapirefraktær revmatoid artritt etter behandlingsforsøk med ikke-steroide antiflogistika eller glukokortikosteroider (4).

Muskelskjelettsymptomer kan være følge av svulstens direkte innvekst eller av spredning (4). Dersom dette ikke er tilfelle, foreligger det en paraneoplastisk tilstand. Selv om man antar at immunprosesser spiller en rolle i patogenesen, er den nøyaktige mekanismen ikke kjent. Bedring av leddsymptomer etter fjerning av tumor er godt dokumentert.

Å være årvåken for muligheten for underliggende cancer ved revmatologiske tilstander kan derved bidra til å diagnostisere malignitet tidligere. Et eksempel fra den praktiske hverdagen er at myelomatose kan manifestere seg initialt med leddsmerter. I utredning med serumelektroforese vil man kunne finne en M-komponent i gammaglobulinfrasjonen og ikke bare inflammatoriske forandringer.

Ved utredning av leddsmerter vil man ønske å identifisere tidlig artritt eller forhøyet risiko for å utvikle en kronisk form for leddgikt. Egne klinikker for tidlig artritt er også opprettet i Norge for å ivareta tidlige symptomer hos pasienter med artritt hvor aggressiv behandling er aktuelt (5)

Sjeldne bindevevssykdommer bør altså diagnostiseres tidlig, ikke minst fordi revmatologiske symptomer, inklusive leddsymptomer, kan være assosiert til malignitet.

\section{Till Uhlig}

till.uhlig@diakonsyk.no

Revmatologisk avdeling

Diakonhjemmet Sykehus

0319 Oslo
Oppgitte interessekonflikter: Ingen

\section{Litteratur}

1. Abu-Shakra M, Buskila D, Ehrenfeld M et al. Cancer and autoimmunity: autoimmune and rheu matic features in patients with malignancies. Ann Rheum Dis 2001: 60: 433-41.

2. Fardet L, Dupuy A, Gain M et al. Factors associated with underlying malignancy in a retrospective cohort of 121 patients with dermatomyositis. Medicine (Baltimore) 2009; 88: 91-7.

3. Stummvoll GH, Aringer M, Machold KP et al. Cancer polyarthritis resembling rheumatoid arthritis as a first sign of hidden neoplasms. Report of two cases and review of the literature. Scand J Rheumatol 2001; 30: 40-4.

4. Naschitz JE, Rosner I. Musculoskeletal syndromes associated with malignancy lexcluding hypertrophic osteoarthropathyl. Curr Opin Rheumatol 2008; $20: 100-5$.

5. Mjaavatten M, Haugen AJ, Helgetveit K et al. Pattern of joint involvement and other disease characteristics in 634 patients with arthritis of less than 16 weeks duration. J Rheumatol 2009; e-publisert 1.6.2009

Manuskriptet ble mottatt 22.5. 2009 og godkjent 4.6. 2009. Medisinsk redaktør Odd Terje Brustugun. 